\title{
A review on zinc and boron nutrition in rice
}

\section{B.M. Suman}

Department of Agronomy, College of Agriculture Vellayani, Kerala Agricultural University, Thiruvananthapuram-695522 (Kerala), India

K Raj Sheeja*

Coconut Research Station, Balaramapuram, Kerala Agricultural University, Thiruvananthapuram-695501(Kerala), India

*Corresponding author. E-mail: sheejakraj70@gmail.com

\begin{abstract}
Micronutrients, though needed in smaller amounts, play a major role in the production and productivity of rice. $\mathrm{Zn}$ is the fourth most deficient nutrient element in Indian soils and its deficiency causes severe yield reduction in rice. Application of $\mathrm{Zn}$ either as foliar spray or soil application caused significant improvement in growth and yield attributes and yield of rice. Similar to that of $\mathrm{Zn}, \mathrm{B}$ nutrition also caused significant improvement in growth and yield attributes and yield of rice. The review elaborates the effect of $\mathrm{Zn}$ and $\mathrm{B}$ nutrition on the growth, physiological parameters, yield attributes, yield and quality of rice.
\end{abstract}

Keywords: Growth attributes, Grain quality, Physiological parameters, Yield attributes, Yield

\section{INTRODUCTION}

Zinc $(\mathrm{Zn})$ plays a major role in the growth and development of rice (Chaudhary et al., 2007). Among the seventeen essential nutrient elements, $\mathrm{Zn}$ is the fourth most deficient nutrient element in Indian soils (Shukla and Behera, 2011). Zinc is one of the vital nutrients which is required for various biochemical and metabolic process in rice such as synthesis of cytochromes and nucleotides, auxin metabolism, production of chlorophyll, activation of several enzymes, membrane integrity, metabolism of carbohydrate, cell wall development, gene expression and respiration (IRRI, 2000; Broadley et al., 2007).

Cereals are more prone to $\mathrm{Zn}$ deficiency than legumes and resulted in substantial reduction in yield and quality (Cakmak et al., 1999). Rehman et al. (2012) reported that $\mathrm{Zn}$ deficiency is considered to be the most important nutritional stresses limiting rice production in Asia. The main factors which affect the $\mathrm{Zn}$ availability to the plants are soil $\mathrm{pH}$, concentration of $\mathrm{Zn}, \mathrm{Fe}, \mathrm{Mn}$ and $\mathrm{P}$ in soil solution, high organic matter and bicarbonate content, high $\mathrm{Ca}$ to $\mathrm{Mg}$ ratio, prolonged submergence and low redox potential.

Zinc deficiency in rice causes a deficiency disorder called Khaira disease. Seedling stage of the crop is highly prone to $\mathrm{Zn}$ deficiency. Leaves develop brown blotches and streaks, the streaks and blotches may fuse to cover the entire leaf, plants remain stunted and in severe case of deficiency the plant may die. Zinc deficiency decreases the

\section{Article Info}

DOI: 10.31018/jans.v10i4.1897

Received: September 17, 2018 Revised: October 29, 2018

Accepted: November 5, 2018

\section{How to Cite}

Suman, B. M. and Sheeja, K.R. (2018). A review on zinc and boron nutrition in rice. Journal of Applied and Natural Science, 10(4): $1180-1186$ 
plants and recorded a plant height of $82.5 \mathrm{~cm}$. Rahman et al. (2008) reported that in boro rice, $\mathrm{Zn}$ applied @ $3 \mathrm{~kg} \mathrm{ha}^{-1}$ along with recommended doses of NPK recorded taller plants. Shivay et al. (2008) conducted an experiment to study the effect of various concentrations of zinc enrichment of urea in aromatic rice-wheat cropping system for two consecutive years and pointed out that application of $3.5 \% \mathrm{Zn}$ enriched urea recorded the tallest rice plants (105.2). Shivay et al. (2010) observed that with the incremental dose of zinc the plant height of aromatic rice cultivars was found to increase and the tallest plants of $103.1 \mathrm{~cm}$ was recorded with the application of $7.5 \mathrm{~kg} \mathrm{Zn} \mathrm{ha}^{-1}$. Taller plants with higher LAI (4.29) at anthesis and higher DMP at harvest were recorded with $6 \mathrm{~kg} \mathrm{Zn}$ ha $^{-1}$ (Singh et al., 2012). Application of $1.5 \% \mathrm{Zn}$ $\left(\mathrm{ZnSO}_{4}\right)$ coated prilled urea and $2 \% \mathrm{Zn}\left(\mathrm{ZnSO}_{4}\right)$ coated prilled urea in Pusa Sugandh 5 , an aromatic semi dwarf rice variety produced taller plants (Shivay and Prasad, 2012). Tillers $\mathrm{m}^{-2}$ were significantly increased by the application of $\mathrm{Zn} @$ $8 \mathrm{~kg} \mathrm{ha}^{-1}$ along with B (Qadir et al., 2013). Zn fertilization along with NPK fertilizers significantly influenced the plant height in rice genotypes compared to NPK fertilization alone (Sudha and Stalin, 2015). Application of Zn @ 10 mg kg-1 soil enhanced the dry matter yield in rice (Kalala et al., 2016). Soil application of $15 \mathrm{~kg} \mathrm{Zn} \mathrm{ha}^{-1}$ just after transplanting recorded maximum plant height of $100 \mathrm{~cm}$ and tillers $\left(430 \mathrm{~m}^{-2}\right.$ ) (Ghoneim, 2016). Oahiduzzaman et al. (2016) reported that $\mathrm{ZnSO}_{4}$ applied @ $4 \mathrm{~kg} \mathrm{ha}^{-1}$ enhanced the plant height at harvest $(88.3 \mathrm{~cm})$ in rice variety, BRRI dhan-33. Foliar application of $\mathrm{Zn}$ along with $\mathrm{Fe}, \mathrm{B}$ and $\mathrm{S}$ recorded taller plants with higher number of tillers, DMP and LAI (Mohan et al., 2017b).

Zinc fertilization on physiological parameters of rice: Li et al. (1999) reported that chlorophyll content and net photosynthetic rate were significantly decreased due to $\mathrm{Zn}$ deficiency. Aravind and Prasad (2004) indicated that $\mathrm{Zn}$ is involved in chlorophyll formation through regulation of nutrients homeostasis in cytoplasm. Zinc plays a crucial role in triggering some of the chlorophyll biosynthetic pathway enzymes (Ayad et al., 2010). Mousavi (2011) reported that foliar or soil application of $\mathrm{Zn}$ increases the biosynthesis of chlorophyll which are important for the photosynthetic process. Zinc fertilization resulted in considerable increase in the chlorophyll content of rice leaves (Mathpal, 2015).

Mustafa et al. (2011) revealed that the CGR was significantly influenced by zinc nutrition. The maximum CGR and total chlorophyll content were registered with the combined application of borax (7.5 $\mathrm{kg} \mathrm{ha}^{-1}$ ) and zinc sulphate (12.5 kg ha-1) (Sarwar et al., 2013). Ghasal et al. (2016) revealed that CGR, RGR and NAR was not significantly influenced by $\mathrm{Zn}$ fertilization, however, the highest values were recorded with soil application of $\mathrm{Zn}$ EDTA @ $1.25 \mathrm{~kg} \mathrm{ha}^{-1}+$ foliar spray of 0.5 per cent at maximum tillering and panicle initiation stage.

Zinc fertilization on yield attributes of rice: Yield attributes were significantly influenced by $\mathrm{Zn}$ fertilization. Soil application of zinc sulphate @ 15 $\mathrm{kg} \mathrm{ha}^{-1}$ significantly influenced the yield components of rice under Faisalabad condition (Maqsood et al., 1999). Khan et al. (2002) reported that application of $10 \mathrm{~kg} \mathrm{ZnSO} \mathrm{Zn}_{4} \mathrm{ha}^{-1}$ recorded the highest number of panicles plant ${ }^{-1}$, spikelets panicle ${ }^{-1}$ and 1000 grain weight. Naik and Das (2007) reported that adequate supply of $\mathrm{Zn}$ produced higher number of panicle $\mathrm{m}^{-2}$. Application of $3.5 \%$ zinc enriched urea significantly influenced the yield attributes of aromatic rice viz., fertile tillers hill $^{-1}$, panicle length and grains panicle ${ }^{-1}$ in rice -wheat cropping system (Shivay et al., 2008). Application of Zn@ $@ 7.5 \mathrm{~kg} \mathrm{ha}^{-1}$ enhanced the yield attributes like panicles hill ${ }^{-1}(9.7)$, panicle length (27.3) and grains panicle ${ }^{-1}(113.4)$ in aromatic rice varieties when compared to control (Shivay et al., 2010). Application of $2 \% \mathrm{Zn}$ coated $\left(\mathrm{ZnSO}_{4}\right)$ prilled urea in aromatic rice variety Pusa Sugandh -5 significantly influenced the yield attributes like panicle hill $^{-1}$ (11.1 and 11.3), panicle length (27.7 and 28.4), number of grains panicle ${ }^{-1}(125.7$ and 128.7 ) and 1000 grain weight (29.3 and 29.8) respectively, during two consecutive years of study (Shivay and Prasad, 2012). Singh et al. $(2012)$ reported that panicles $\mathrm{m}^{-2}$ and grains panicle $^{-1}$ were significantly enhanced by the application of $\mathrm{Zn} @ 6 \mathrm{~kg} \mathrm{ha}^{-1}$. Soil application of $\mathrm{ZnSO}_{4}$ @ $40 \mathrm{~kg} \mathrm{ha}^{-1}$ increased the panicle $\mathrm{m}^{-2}$ and fertile grains panicle ${ }^{-1}$ (Yadi et al., 2012). Qadir et al. (2013) reported that Zn applied @ 8 kg ha ${ }^{-1}$ increased the panicle $\mathrm{m}^{-2}$, spikelets panicle ${ }^{-1}$ and fertility percentage (73.90 per cent). Grains pani$\mathrm{cle}^{-1}$ and panicle length was enhanced by the application of $\mathrm{Zn}$ as basal and foliar spray at flowering, milk and dough stages of rice (Sudha and Stalin, 2015). The highest number of panicle $\mathrm{m}^{-2}$ (350), number of spikelets panicle ${ }^{-1}$ (129), filled grains (82 per cent) and 1000 grain weight (27.1 g) were recorded with the soil application of $15 \mathrm{~kg}$ $\mathrm{Zn} \mathrm{ha}{ }^{-1}$ just after transplanting in rice (Ghoneim, 2016). Oahiduzzaman et al. (2016) opined that higher number of productive tillers hill $^{-1}$ and filled grains panicle ${ }^{-1}$ were recorded with $4 \mathrm{~kg} \mathrm{Zn} \mathrm{ha}^{-1}$. Foliar spray of $\mathrm{ZnSO}_{4} @ 10 \mathrm{~kg} \mathrm{ha}^{-1}$ along with recommended dose of NPK enhanced the yield attributing characters like productive tillers $\mathrm{m}^{-2}$, grains panicle ${ }^{-1}$ and test grain weight (Mohan et al., 2017b).

Zinc fertilization on rice yield: $\mathrm{Zn}$ fertilization had significant effect on the grain yield of rice and highest grain yield was recorded with the application of $\mathrm{ZnSO}_{4} @ 10 \mathrm{~kg} \mathrm{ha}{ }^{-1}$ (Khan et al., 2002). Foliar nutrition of $\mathrm{Zn}$ enhanced the grain yield in rice (Potarzycki and Grzebisz, 2009). In an experi- 
ment conducted in rice-wheat cropping system, aromatic rice recorded the highest grain (4.12 and $\left.5.45 \mathrm{t} \mathrm{ha}^{-1}\right)$ and straw yield (10.95 and $12.64 \mathrm{t} \mathrm{ha}^{-}$ $\left.{ }^{1}\right)$ with the application of $3.5 \% \mathrm{Zn}$ enriched urea (Shivay et al., 2008). Shivay et al. (2010) reported that application of Zn @ $7.5 \mathrm{~kg} \mathrm{ha}^{-1}$ recorded the highest straw yield of $10.99 \mathrm{t} \mathrm{ha}^{-1}$ in aromatic rice. Soil application of $25 \mathrm{~kg} \mathrm{ZnSO}_{4} \mathrm{ha}^{-1}$ along with $120 \mathrm{~kg} \mathrm{ha}^{-1}$ prilled urea recorded the highest grain yield of $5.18 \mathrm{t} \mathrm{ha}^{-1}$ in aromatic rice variety Pusa Sugandh-5 (Yadav et al., 2010). Fageria et al. (2011) reported that $\mathrm{Zn}$ fertilization resulted in 97 per cent increase in grain yield. Mustafa et al. (2011) opined that method and time of application of $\mathrm{Zn}$ significantly influenced the grain yield of rice. They also reported that soil application of $\mathrm{ZnSO}_{4}\left(25 \mathrm{~kg} \mathrm{ha}^{-1}\right)$ recorded higher grain yield compared to 0.5 per cent $\mathrm{Zn}$ foliar spray at 75 DAT. Application of $2 \% \mathrm{Zn}$ coated $\left(\mathrm{ZnSO}_{4}\right)$ prilled urea in aromatic rice variety Pusa Sugandh-5 recorded the highest grain ( 5.26 and $\left.5.29 \mathrm{t} \mathrm{ha}^{-1}\right)$ and straw yield $\left(11.23\right.$ and $\left.11.31 \mathrm{t} \mathrm{ha}^{-1}\right)$ respectively, during the consecutive years of study (Shivay and Prasad, 2012). The highest grain yield $\left(7.63 \mathrm{t}\right.$ ha ${ }^{-}$ $\left.{ }^{1}\right)$ was recorded with $\mathrm{Zn}$ applied @ $6 \mathrm{~kg} \mathrm{ha}^{-1}$ (Singh et al., 2012). Yadi et al. (2012) pointed out that as the rate of application increased from 20 to $30 \mathrm{~kg} \mathrm{Zn} \mathrm{ha}{ }^{-1}$, corresponding increase in grain yield was observed in two rice varieties tested. Application of $\mathrm{Zn}$ and B @ 8 and $2 \mathrm{~kg} \mathrm{ha}^{-1}$ along with recommended NPK recorded the highest grain and straw yield (Qadir et al., 2013). Rana and Khasif (2014) reported that foliar application of $\mathrm{Zn}$ resulted in higher grain yield than soil application. Shivay et al. (2015) reported that soil application (5 $\mathrm{kg} \mathrm{Zn} \mathrm{ha}^{-1}$ ) plus foliar application (1 kg $\mathrm{Zn} \mathrm{ha}{ }^{-1}$ ) recorded the highest grain and straw yield in rice. Application of $\mathrm{Zn} @ 5 \mathrm{mg} \mathrm{kg}^{-1}$ soil was found optimum for obtaining good yield in soils deficient in Zn (Kalala et al., 2016). Oahiduzzaman et al. (2016) revealed that Zn applied @ 4 $\mathrm{kg} \mathrm{ha}^{-1}$ recorded higher grain $\left(5.1 \mathrm{t} \mathrm{ha}^{-1}\right)$ and straw $\left(6.6 \mathrm{t} \mathrm{ha}^{-1}\right)$ yield in BRRI dhan-33 rice variety. Foliar spray of one per cent $\mathrm{Zn}$ salt at tillering and flag leaf stage significantly enhanced the grain and straw yield (Kulhare et al., 2017).

Zinc fertilization on $\mathrm{Zn}$ availability in soil and uptake by rice: Zinc fertilization had significant effect on Zn uptake by rice plant (Salam and Subramanian, 1988). Zinc levels and genotypes had significant effect on $\mathrm{Zn}$ content in shoot and grain (Fageria and Baligar, 2005). The total uptake of zinc was recorded the highest with the application of $3.5 \% \mathrm{Zn}$ enriched urea in aromatic rice under rice-wheat cropping system (Shivay et al., 2008). Fageria et al. (2011) reported that application of $120 \mathrm{mg} \mathrm{Zn} \mathrm{kg}^{-1}$ of soil recorded the highest uptake of $\mathrm{Zn}$ in shoot $\left(20.01 \mathrm{mg} \mathrm{pot}^{-1}\right)$ and grain $\left(1.77 \mathrm{mg} \mathrm{pot}^{-1}\right)$, respectively. Zinc content and $\mathrm{Zn}$ uptake were significantly influenced by various levels of $\mathrm{Zn}$. The highest $\mathrm{Zn}$ content and uptake was recorded with $\mathrm{Zn} @ 7.5 \mathrm{mgkg}^{-1}$ soil (Muthukumararaja and Sriramachandrasekharan, 2012). Zinc content of brown rice was increased significantly over the control by the foliar and soil application of Zn (Phattarakul et al., 2012). Shivay and Prasad (2012) reported that the highest zinc uptake (1346.3 and $1325.1 \mathrm{~g} \mathrm{ha}^{-1}$ respectively) was recorded with the application of $2 \% \mathrm{Zn}$ coated $\left(\mathrm{ZnSO}_{4}\right)$ prilled urea in aromatic rice variety Pusa Sugandh-5 during both the consecutive years of study. Foliar spray of $0.5 \% \mathrm{ZnSO}_{4}$ after flowering increased the $\mathrm{Zn}$ content in paddy (Boonchauay et al., 2013). The highest uptake of $Z n$ was registered with the soil application of $5 \mathrm{~kg} \mathrm{Zn} \mathrm{ha}^{-1}+$ foliar application of $1 \mathrm{~kg} \mathrm{Zn} \mathrm{ha}^{-1}$ (Shivay et al., 2015). Rana and Kashif (2014) reported that $\mathrm{Zn}$ content in the paddy and straw were increased with the application of Zn-EDTA @ 10 kg ha ${ }^{-1}$. Zinc application enhanced the $\mathrm{Zn}$ content of whole grain by 30 to 53 per cent over control (Sudha and Stalin, 2015). Kumar et al. (2017) reported that soil application of $\mathrm{ZnSO}_{4} @ 50 \mathrm{~kg} \mathrm{ha}^{-1}$ recorded higher $\mathrm{Zn}$ content in grain which was statistically on par with foliar spray of $\mathrm{Zn}$-EDTA equivalent to 0.2 per cent $\mathrm{ZnSO}_{4}$. Kulhare et al. (2017) reported that foliar spray of one per cent $\mathrm{Zn}$ salt significantly increased the $\mathrm{Zn}$ uptake by grain.

Srivastava et al. (1999) pointed out that $\mathrm{Zn}$ fertilization significantly increased the available $\mathrm{Zn}$ content in the soil over control (no Zn). Khan et al. (2004) reported that soil application of $15 \mathrm{~kg} \mathrm{Zn} \mathrm{ha}$ recorded the highest $\mathrm{Zn}$ content of $0.773 \mathrm{ppm}$. Zinc content in the soil was significantly influenced by different levels of Zn. Application of Zn @ 6 kg $\mathrm{ha}^{-1}$ recorded the highest available $\mathrm{Zn}$ content (0.98 ppm) (Singh et al., 2012). Comparing the different sources of $\mathrm{Zn}$, Kulhare et al. (2017) found that available $\mathrm{Zn}$ content in the soil was highest with $\mathrm{Zn}$-EDTA and $\mathrm{ZnSO}_{4}$ compared to $\mathrm{ZnCl}_{2}, \mathrm{Zn}_{3}$ $\left(\mathrm{PO}_{4}\right)_{2}$ and $\mathrm{ZnO}$.

Zinc fertilization on quality parameters of rice: $\mathrm{Li}$ et al. (1999) observed that quality of rice grain was enhanced by $\mathrm{Zn}$ fertilization. However, Khan et al. (2004) observed that $\mathrm{Zn}$ fertilization adversely affected the starch content of the paddy grain. Hossain et al. (2008) indicated that Zn levels did not have any significant effect on the protein content of grain, whereas the starch content significantly varied with the $\mathrm{Zn}$ levels and the highest starch content (73.15 per cent) was recorded with $\mathrm{ZnSO}_{4}$ foliar spray at 0.5 per cent. Application of $\mathrm{Zn}$ along with $\mathrm{N}$ significantly enhanced the water absorption ratio and protein content of the grain (Khan et al., 2009). Application of $\mathrm{Zn}$ as basal and foliar application at flowering, milk and dough stages enhanced the crude protein and starch content in rice from 56.28 to 82.48 per cent and 5 to 19 per cent, respectively over control (Sudha and Stalin, 2015). Kumar et al. (2017) reported that the high- 
est grain protein content was observed with soil application of $\mathrm{ZnSO}_{4} @ 50 \mathrm{~kg} \mathrm{ha}{ }^{-1}$. Mohan et al. (2017a) reported that foliar application of $10 \mathrm{~kg}$ zinc sulphate $+5 \mathrm{~kg}$ ferrous sulphate $+10 \mathrm{~kg}$ borax $+10 \mathrm{~kg}$ sulphur ha ${ }^{-1}$ along with recommended dose of NPK recorded the highest protein content (8.875 per cent).

Boron fertilization on growth attributes of rice: Application of $B$ enhances the growth attributes due to its favourable influence on metabolic pathways involved in cell division and elongation (Hatwar et al., 2003). Ahmad et al. (2012) pointed out that foliar spray of B and Si at 0.5 per cent and 1.5 per cent recorded the highest plant height $(107.17 \mathrm{~cm})$. Arif et al. (2012) revealed that foliar spray of B and Zn @ 3 and $6 \mathrm{~kg} \mathrm{acre}^{-1}$ enhanced the plant height $(121 \mathrm{~cm})$ and tillers plant ${ }^{-1}$. Qadir et al. (2013) opined that higher number of tillers were recorded with the soil application of $B$ and Zn@ 2 and 8 kg ha ${ }^{-1}$. Rehman et al. (2014) also reported that foliar application of $0.24 \mathrm{M} \mathrm{B}$ had significant effect on tiller production in cultivars, Super basmati and Shaheen basmati. The dry matter production was also significantly influenced by foliar spray of B @ $20 \mathrm{mg} \mathrm{L}^{-1}$ (Ali et al., 2016). The highest DMP of $15.57 \mathrm{t} \mathrm{ha}^{-1}$ was recorded with the application of borax $10 \mathrm{~kg} \mathrm{ha}^{-1}$ along with FYM 5t ha ${ }^{-1}$, recommended NPK and lime $600 \mathrm{~kg}$ $\mathrm{ha}^{-1}$ in Kole lands of Kerala (Rani and Latha, 2017).

Boron fertilization on physiological parameters of rice: Soil application of B and Zn @ 3 and $6 \mathrm{~kg}$ acre $^{-1}$ enhanced the chlorophyll $\mathrm{a}, \mathrm{b}$ and the total chlorophyll content (Arif et al., 2012). Chlorophyll content is increased by the application of $B$ and $\mathrm{Zn}$ (Pervaiz et al., 2012). Rehman et al. (2014) reported that foliar spray of $0.16 \mathrm{M} \mathrm{B}$ and $0.24 \mathrm{M} \mathrm{B}$ recorded higher total chlorophyll contents in rice varieties Super basmati and Shaheen basmati.

Boron fertilization on yield attributes of rice: Boron fertilization had profound influence on the production of yield attributes. Ahmad et al. (2012) reported that foliar spray of one per cent $B$ and 0.5 per cent $\mathrm{Si}$ produced panicles with more length. Soil application of B and Zn @ 1.5 and 3 $\mathrm{kg} \mathrm{acre}{ }^{-1}$ enhanced the panicle length $(30.40 \mathrm{~cm})$ (Arif et al., 2012). Boron was applied along with $\mathrm{Zn}$ and $\mathrm{Fe}$ resulted in the production of higher number of spikelets panicle ${ }^{-1}$ and grains with higher test grain weight (Qadir et al., 2013). Application of $0.24 \mathrm{M} \mathrm{B}$ recorded higher number of productive tillers and grain yield plant ${ }^{-1}$, however, the lowest sterility percentage was recorded with the application of 0.32 M B (Rehman et al., 2014). Remesh and Rani (2017) found that grain weight panicle $^{-1}$ was enhanced by the soil application of B@ $@ \mathrm{~kg} \mathrm{ha}^{-1}$ and foliar application of B@ $250 \mathrm{mg}$ $\mathrm{L}^{-1}$. Ali et al. (2016) reported that higher number of filled grains panicle ${ }^{-1}$ were recorded with the appli- cation of $20 \mathrm{mg} \mathrm{B} \mathrm{L}^{-1}$. Rani and Latha (2017) reported that higher number of spikelets panicle ${ }^{-1}$ (96.41) and filled grains panicle ${ }^{-1}(94.30)$ were recorded with application of borax $10 \mathrm{~kg} \mathrm{ha}^{-1}$ along with FYM 5t ha ${ }^{-1}$, recommended NPK and lime $600 \mathrm{~kg} \mathrm{ha}^{-1}$ in Kole lands of Kerala which was $45 \%$ more than that of the control.

Boron fertilization on rice yield: The grain yield was increased with the application of $B$ at heading or flowering stage of rice (Ramanathan et al., 2002). Grain yield was significantly improved by foliar spray of one per cent B and 1.5 per cent Si (Ahmad et al., 2012). Rice growth and grain yield were enhanced by the soil application of $B$ in soils deficient in B (Hussain et al., 2012). Soil application of $B$ and $Z n @ 3$ and 6 kg acre ${ }^{-1}$ recorded the highest grain and straw yield (4.18 and $13.84 \mathrm{t}$ ha ${ }^{1}$, respectively) (Arif et al., 2012). Ali et al. (2016) observed that foliar application of B @ 20 mg L ${ }^{1}$ recorded the highest grain yield. Remesh and Rani (2017) opined that soil application of B @ $1 \mathrm{~kg} \mathrm{ha}^{-1}$ recorded the highest grain yield $(5502.85$ $\left.\mathrm{kg} \mathrm{ha}^{-1}\right)$. Rani and Latha (2017) reported that application of borax @10 kg ha-1 along with recommended dose of NPK recorded the highest grain yield of $7.67 \mathrm{t} \mathrm{ha}^{-1}$.

Boron fertilization on $B$ availability in soil and uptake by rice: Application of $B$ fertilizer enhances the uptake of $B$ within the rice plant, but only less than 40 per cent is stored in grain and remaining portion is accumulated in leaves and stem (Katyal and Singh,1992). Arif et al. (2012) revealed that soil application of $B$ and $Z n @ 3$ and $6 \mathrm{~kg}$ acre $^{-1}$ recorded higher $B$ and $\mathrm{Zn}$ content in rice. Soil application of $B$ and $Z n @ 10$ and 2 kg ha -1 increased the $B$ and $\mathrm{Zn}$ content of rice grain (Bhutto et al., 2013). Boron content in leaves and kernels was found to enhance with the increasing concentration of foliar applied B in cultivars Super basmati and Shaheen basmati (Rehman et al., 2014).

Boron fertilization on quality parameters of rice: The quality of grain is enhanced by the application of B@0.75 kg ha ${ }^{-1}$ (Rashid et al., 2009). Ahmad et al. (2012) reported that highest grain protein content $(6.89 \%)$ was recorded with the application of 1 per cent $B$ and highest grain starch content was obtained with the application of $\mathrm{B}$ and $\mathrm{Si}$ at 1 and 1.5 per cent, respectively.

\section{Conclusion}

It was concluded that the main factors affecting the $\mathrm{Zn}$ availability to the rice plant are soil $\mathrm{pH}$, concentration of $\mathrm{Zn}, \mathrm{Fe}, \mathrm{Mn}$ and $\mathrm{P}$ in the soil solution, organic matter content, bicarbonate content, high $\mathrm{Ca}$ to $\mathrm{Mg}$ ratio, moisture content in the soil and redox potential of the soil. Zinc fertilization had significant effect on its growth, yield attributes and yield. It also had significant effect on total chlorophyll content and net photosynthetic rate 
due to active role in the biosynthesis of chlorophyll. Also, Zn fertilization significantly improved the $\mathrm{Zn}$ uptake by crop and $\mathrm{Zn}$ content in the rice grain. The quality of rice grain was also enhanced by $\mathrm{Zn}$ fertilization. Boron also plays a major role in the growth and development of rice due to its metabolic involvement in the metabolic pathways involved in cell division and cell elongation, calcium utilization, flowering/fruiting, disease resistance, water relations and act as catalyst for several reactions. It is also very much essential for the metabolism of carbohydrate, transport of sugars, synthesis of nucleotide, respiration and pollen viability. Deficiency of B affects the plant growth. The soil factors affected the B deficiency in soil are low moisture content, acidity, calcareous nature of soil, leaching and fixation. Boron fertilization had profound influence on the production of growth and yield attributes and finally resulted in higher grain yield. The grain protein and starch content were significantly improved with the foliar nutrition of B. Hence $\mathrm{Zn}$ and B are very vital for rice production and its deficiency in soil may cause significant reduction in rice grain yield.

\section{REFERENCES}

1. Ahmad, A., Tahir, M., Ullah, E., Naeem, M., Ayub, M., Rehman, H., and Talha, M. (2012). Effect of silicon and boron foliar application on yield and quality of rice. Pak. J. life Soc. Sci. 10 (2): 161-165.

2. Ali, S., Raza, S.A., Butt, S.J., and Sarwar, Z. (2016). Effect of foliar boron application on rice (Oryza Sativa L.) growth and final crop harvest. Agric. and Food Sci. Res. 3(2): 49-52.

3. Aravind, P. and Prasad, M.N.V. (2004). Zinc protects chloroplasts and associated photochemical functions in cadmium exposed Ceratophyllum dermesum L., a freshwater macrophyte. Plant Sci. 166: 1321-1327.

4. Arif, M., Shehzad, M.A., Bashir, F., Tasneem, M., Yasin, G., and Iqbal, M. (2012). Boron, zinc and microtone effects on growth, chlorophyll contents and yield attributes in rice (Oryza sativa L.) cultivar. Afr. J. Biotechnol. 11(48): 10851-10858.

5. Ayad, H.S., Reda, F., and Abdalla M.S.A. (2010). Effect of putrescine and zinc on vegetative growth, photosynthetic pigments, lipid peroxidation and essential oil content of geranium (Pelargonium graveolens L.). World J. Agric. Sci. 6 601- 608.

6. Bhutto, M.A., Maqsood, Z.T., Arif, S., Riazuddin., Iqbal, S., Mahmood, Q., Akhlaq, A., Bhutto, R., Moheyuddin, K., Mari, A.H., Panhwar, R.N., and Salahuddin, J. (2013). Effect of zinc and boron fertilizer application on uptake of some micronutrients into grain of rice varieties. J. Agric. Environ. Sci, 13 (8): 1034-1042.

7. Boonchauay, P., Cakmak, I., Rekasem, B., and ProU-thai, C. (2013). Effect of different foliar zinc application at different growth stages on seed zinc concentration and its impact on seedling vigour in rice. Soil Sci. Plant Nutr. 59: 180-188.

8. Broadley, M.R., White, P.J., Hammond, J.P., Zelko, I., and Lux, A. (2007). Zinc in plants. New phytol. 173: 677-702.

9. Cakmak.I., Kalayci, M., Ekiz, H., Braun, H.J., Kiline,
Y. and Yilmaz, A. (1999). Zinc deficiency as a practical problem in plant and human nutrition in Turkey: A NATO-science for stability project. Field Crop Res. 60: $175-188$.

10.Chaudhary, S.K., Thakur, S.K., and Pandey, A.K. (2007). Response of wet land rice to nitrogen and zinc. Oryza. 44 (1): 31-34.

11.Dell, B. and Huang, L. (1997). Physiological response of plants to low boron. Plant and soil.193: 103 $-120$.

12.Fageria, N.K. and Baligar, V.C. (2005). Growth components and zinc recovery efficiency of upland rice genotypes. Brasilia. 40 (12): 1211-1215.

13.Fageria, N.K., Moreira, A., and Coelho, A.M. (2011). Yield and yield components of upland rice as influenced by nitrogen sources. J. Plant Nutr. 34: 361 370.

14.Ghasal, P.C., Shivay, Y.S., Pooniya, V., Kumar, P., and Verma, R.K. (2016). Zinc fertilization enhances growth and quality parameters of aromatic rice (Oryza sativa L.). Indian J. Plant Physiol. 21(3): 323332.

15.Ghoneim, A.M. (2016). Effect of Different Methods of $\mathrm{Zn}$ application on rice growth, yield and nutrients dynamics in Plant and soil. J. Agric. Ecol. Res. Int. 6 (2): $1-9$.

16. Hatwar, G.P., Gondane, S.M., Urkade, S.M., and Ahukar, V. (2003). Effect of micronutrients on growth and yield of chilli. Soils Crops 13 (1): 123-125.

17.Hossain, M., Hannan, M.A., Talukder, N.M., and Hanif, M.A. (2008). Effect of different rates and methods of zinc application on the yield and nutritional qualities of rice cv. BR11. J. Agrofor. Environ. 2 (1): 1 -6 .

18.Hussain, M., Khan, M.A., Khan, M.B., Farooq, M., and Farooq, S. (2012). Boron application improves growth, yield and net economic return of rice. Rice Sci. 19 (3): 259-262.

19.IRRI [International Rice Research Institute] (2000). Nutritional disorders and nutrient management in rice. International Rice Research Institute, Manila, Philipines.

20.Kalala, A.M., Amuri, N.A., and Semoka, J.M.R. (2016). Sulphur and zinc fertilization effects on growth and yield response of rice. Int. J. Plant. Soil Sci. 11(5): 1-12.

21.Kumar, D., Kumar, R., Singh, P., and Kumar, P. (2017). Effect of different zinc management practices on growth, yield, protein content, nutrient uptake and economics of rice under partially reclaimed salt affected soil. J. Pharmacognosy and phytochem. 6 (5): 638-640.

22.Katyal, J.C. and Singh, B. (1992). Availabilty of boron in soils and and uptake by rice as influenced by moisture regime. J. Agric. Res. 48 (3): 303-314.

23.Khan, M.U., Qasim, M., and Jamil, M. (2002). Response of rice to zinc fertilizer in calcareous soils of D. I. Khan. Asian J. Plant Sci. 1 (1): 1-2.

24.Khan, M.U., Qasim, M., and Jamil, M. (2004). Effect of zinc on starch content of paddy and zinc content of soil, leaf and root of rice grown in calcareous soils. Int. J. Agric. Biol. 6 (6): 1132-1135.

25.Khan, R., Gurumani, A.R., Khan, M.S., and Gurumani, A.H. (2009). Residual, direct and cumulative effect of zinc application on wheat and rice yield under ricewheat system. Soil. Environ. 28 (1): 24-28.

26.Kulhare, P.S., Tagore, G.S., and Sharma, G.D. 
(2017). Effect of foliar spray and sources of zinc on yield, zinc content and uptake by rice grown in a vertisol of central India. Int. J. Chem. Stud. 5 (2): 3538.

27.Li., Yan., Qin., Suichu., Li, Y., and Qin, S.C. (1999). Effect of rice metabolism and the diagnosis of hidden zinc deficiency in rice. J. Fujian Agric. Univ. 28 (1): 66-67.

28.Mathpal, B., Srivastava, P.C., Shankdhar, D., and Shankhdhar, S.C. (2015). Improving key enzyme activities and quality of rice under various methods of zinc application. Physiol. Mol. Biol. Plants. 21 (4): 567-572.

29.Maqsood, M., Irshad, M., Wajid, S.A., and Hussain, A. (1999). Growth and yield response of Basmati-385 (Oryza sativa L.) to $\mathrm{ZnSO}_{4}$ application. Pak. J. Biol. Sci. 2 (4): 1632-1633.

30.Mengel, K. and Kirkby, E. A. (2001). Boron. Principles of Plant Nutrition ( $5^{\text {th }}$ ed.). Kluwer Academic Publishers Dordrecht/ Boston/ London, Netherlands

31.Mohan, A., Tiwari, A., Kumar, M., Pandey, D., Singh, A., and Singh, B. (2017a.) Effect of foliar spray of various nutrients on performance of rainfed rice (Oryza sativa L.). J. of pharmacognosy and phytochem. 6 (5): 2252-2256.

32.Mohan, A., Tiwari, A., and Singh, B. (2017b). Effect of foliar spray of various nutrients on yield attributes, yield and economics of rainfed rice. Int. J. Curr. Microbiol. App. Sci. 6 (10): 2566-2572.

33.Mousavi, R.S. (2011). Zinc in crop production and interaction with phosphorous. Aust. J. Basic. Appl. Sci. 5 (9): 1503-1509.

34.Mustafa, G., Enshanullah., Akbar, N., Qaisrani, S.A., Iqbal, A., Khan, Z.H., Jabran, K., Chattha, A.A., Trethowan, R., Chattha, T., and Atta, B.M. 2011. Effect of zinc application on growth and yield of rice. Int. J. Agro Vet. Med. Sci. 5 (6): 530-535.

35.Muthukumararaja, T.M. and Sriramachandrasekharan, M.V. (2012). Effect of zinc on yield, zinc nutrition and zinc use efficiency of lowland rice. $J$. Agric. Technol. 8 (2): 551-561.

36.Naik, S.K. and Das, D.K. (2007). Effect of split application of zinc on yield of rice (Oryza sativa L.) in an inceptisol. Arch. Agron. Soil Sci. 53: 305-313.

37.Niaz, A., Ibrahim, M., Nisar, A. and Anwar, S. A. (2002). Boron contents of light and medium textured soils and cotton plants. Int. J. Agric. Biol. 4: 534-536.

38.Niaz, A., Ranjha, A. M., Rahmatullah, Hannan, A. and Waqas, M. (2007). Boron status of soils as affected by different soil characteristics-pH, $\mathrm{CaCO}_{3}$, organic matter and clay contents. Pak. J. Agric. Sci. 44: 428-435.

39.Oahiduzzaman, M., Shovon, S.C., Mahjuba, A., Mehraj, H., and Uddin, A. F. M. J. (2016). Different zinc levels on growth, yield and nutrient content of BRRI dhan 33. J. Biosci. Agric. Res. 9 (2): 820-826.

40.Pervaiz, K., Yousuf, M., Imtiaz, M., Depar, M., Aslam, M., Suleman., and Javed, A.S. (2012). Determining the zinc requirements of rice genotype sarshar evolved at NIA, Tandojam. Sarhad J. Agric. 28 (1):1-7.

41.Phattarakul, N., Rerkasem, B., and Li, L.J. (2012). Biofortification of rice grain with zinc through zinc fertilization in different countries. Plant soil. 361 (1-2): 131-141.

42.Potarzycki, J. and Grzebisz, W. (2009). Effect of zinc foliar application on grain yield of maize and its yielding components. Plant Soil Environ. 55 (12): 519-527.

43.Qadir, J., Awan, I.U., Baloch, M.S., Shah, I.H., Nadim, M.A., Saba, N., and Bakhsh, I. (2013). Application of micronutrients for yield enhancement in rice. Gomal Univ. J. of Res. 29 (2): 9-16.

44.Rahman, M.T., Jahiruddin, M., Humauan, M.R., Alam, J.M., and Khan, A. A. (2008). Effect of sulphur and zinc on growth, yield and nutrient uptake of boro rice (CV. BRRI dhan 29). J. Soil. Nat. 2 (3): 10-15.

45.Ramanathan, S., Stalin, P., Thilagavathi, T., Natarajan, K., and Ankorion, Y. (2002). Foliar nutrition of peak on rice. In: Proceeding of the $17^{\text {th }}$ WCSS, 1421August, Thailand, pp. 2231-2242.

46. Rani, P.S. and Latha, A. (2017). Effect of calcium, magnesium and boron on nutrient uptake and yield of rice in Kole lands of Kerala. Indian J. Agric. Res., 51 (4) 2017: 388-391.

47.Rana, W.K. and Khashif, S.R. (2014). Effect of different zinc sources and methods of application on rice yield and nutrient concentration in rice grain and straw. J. Environ. Agric. Sci. 1:9.

48. Rashid, A. and Rayan, J. (2004). Micronutrient constraints to crop production in soils with Mediterranean type characteristics: A review. J. Plant Nutr. 27:959975.

49.Rashid, A., Yasin, A. and Ali, M.A. (2009). Boron deficiency in rice in Pakistan: A serious constraint to productivity and grain quality, In: Ashraf, M., Ozturk, M. and Athar, H.R. (eds), Salinity and Water Stress: Improving Crop Efficiency, Springer Science + Business Media, BV, pp.213-219.

50.Rashid, A., Muhammad, S. and Rafique, E. (2005). Rice and wheat genotypic variation in boron use efficiency. Soil Environ. 24: 98-102.

51.Rehman, A., Farooq, M., Cheema, Z.A., Nawaz, A. and Wahid, A. (2014). Foliage applied boron improves the panicle fertility, yield and biofortification of fine grain aromatic rice.J. of Soil Sci. and Plant. Nutr. 14 (3): 723-733.

52.Rehman, H., Farooq, M., and Basra, S.M.A. (2012). High grain $\mathrm{Zn}$ concentration results from increased $\mathrm{Zn}$ supply and remobilization during grain filling in water saving rice cultivation [abstract]. In: Abstracts of $14^{\text {th }}$ Congress of soil Science, 12-15 March, 2012, Lahore, Pakistan.

53.Remesh, R. and Rani, B. (2017). Effect of boron application through soil and foliar methods on the yield attributes and nutrient uptake of wet land rice. Agric. update. 12: 301-304.

54.Salam, A.M. and Subramanian, S. (1988). Influence of nitrogen, zinc and their interaction on the yield and nutrient uptake of IR20 rice (Oryza sativa) in different seasons. Indian J. Agric. Sci. 58 (3): 190-193.

55.Sarwar, N., Ali, H., Ahmad, A., Ullah, E., Ahmad, S., Mubeen, K., and Hill, J.E. (2013). Water wise rice cultivation on calcareous soils with the addition of essential micronutrients. J. Anim. Plant. Sci. 23 (1): 244-250.

56.Shivay, S.Y., Kumar, D., and Prasad, R. (2008). Effect of $\mathrm{Zn}$ enriched urea on productivity, zinc uptake and efficiency of an aromatic rice-wheat cropping system. Nutr. Cycl. Agroecosyst. 81: 229-243.

57.Shivay, Y.S., Kumar, D., and Prasad, R. (2008). Effect of zinc enriched urea on productivity, zinc uptake and efficiency of an aromatic rice-wheat cropping system. Nutr. Cycl. Agroecosyst. 81:229-243. 
58.Shivay, Y.S., Prasad, R., and Anshu, R. (2010). Genotypic variation for productivity, zinc utilization efficiencies and kernel quality in aromatic rice under low available zinc conditions. J. Plant Nutr. 33:18351848.

59.Shivay, Y.S. and Prasad, R. (2012). Zinc coated urea improves productivity and quality of Basmati rice (Oryza sativa L.) under zinc stress conditions. J. Plant Nutr. 35: 928-951.

60.Shivay, Y.S., Prasad, R., Singh, R.K., and Pal, M. (2015). Relative efficiency of zinc coated urea and foliar application of zinc sulphate on yield, nitrogen, phosphorous, potassium, zinc and iron biofortification in grains and uptake by Basmati rice (Oryza sativa L.). J. Agric. Sci. 7 (2): 161-173.

61.Shukla, A.K. and Behera, S.K. (2011). Zinc management in Indian agriculture. Indian J. Fertil. 7: 14-33.

62.Singh, A.K., Manibhushan., Meena, M.K., and Upadhyaya, A. (2012). Effect of sulphur and zinc on rice performance and nutrient dynamics in plants and soils of Indo gangetic plains. J. Agric. Sci. 4 (11): 162
63.Slaton, N.A., Wilson, C.E., Norman, R.J., and Boothe, D.L. (2001). Evaluation of zinc seed treatments for rice. J. Agron. 93: 152-157.

64.Spraque, H.B. (1951). Hunger Signs in Crops. Mckay, Newyprk, USA.

65.Srivastava, P.C., Ghosh, D., and Singh, V.P. 1999. Evaluation of different zinc sources for lowland rice production. Biol. Fert. Soils. 30: 168-172.

66.Sudha, S. and Stalin, P. (2015). Effect of zinc on yield, quality and grain zinc content of rice genotypes. Int. J. Farm Sci. 5 (3): 17-27.

67.Yadav, G.S., Kumar, D., Shivay, Y.S., and Singh, H. (2010). Zinc-enriched urea improves grain yield and quality of aromatic Rice. Better Crops. 94 (2):6-7.

68. Yadi, R., Dastan, S., and Yasari, E. (2012). Role of zinc fertilizer on grain yield and some qualities parameters in Iranian rice genotypes. Ann. Biol. Res. 3 (9): 4519-4527.

69. Yu and Bell. (1998). Nutrient deficiency symptoms and boron uptake mechnisms of rice. J. Plant Nutr. 21: 2077-2088. 